\title{
RELATION BETWEEN LENGTH OF STAY AND ANTI-FILARIAL IgG4 LEVEL IN PONDOK GEDE SUB-DISTRICT, BEKASI DISTRICT, WEST JAVA
}

\author{
Jeffry Adijaya Susatyo ${ }^{1}$, Heri Wibowo ${ }^{2}$ \\ ${ }^{1}$ Medical Doctor Program, ${ }^{2}$ Department of Parasitology, Faculty of Medicine, Universitas Indonesia
}

\begin{abstract}
ABSTRAK
Filariasis adalah penyakit menular yang disebabkan oleh cacing dari genus Filaria yang ditularkan melalui gigitan berbagai jenis nyamuk. Di Indonesia, keberadaan kasus filariasis masih sangat memprihatinkan. Desa Jati Sampurna dan Jati Karya di Kecamatan Pondokgede, Kabupaten Bekasi, Jawa Barat telah dikenal sebagai daerah endemik filariasis. Lama menginap dianggap sebagai salah satu dari banyak faktor yang mempengaruhi kejadian filariasis di desa-desa tersebut. Penelitian ini bertujuan untuk mengetahui distribusi IgG4 anti-filaria di wilayahnya dan perbandingannya dengan lama tinggal dan status kependudukan. Penelitian ini didasarkan pada data sekunder. Data sekunder diperoleh dari data penelitian primer dengan metode cross-sectional. Data ini digunakan untuk menilai hubungan faktor risiko infeksi filaria pada ibu hamil yang tinggal di daerah endemik berdasarkan distribusi IgG4 anti-filaria di Pondok Gede, Kabupaten Bekasi, Jawa Barat. Penelitian menunjukkan adanya peningkatan IgG4 antifilaria terhadap status kependudukan $(p=0,017)$ dan korelasi positif antara jumlah IgG4 anti-filaria dengan lamanya tinggal selama bertahun-tahun ( $p=0,003)$. (FMI 2017;53:217-219)
\end{abstract}

Kata kunci: IgG4 anti-filaria; masa tinggal; status kependudukan

\begin{abstract}
Filariasis is a contagious disease caused by worms of the genus Filaria which transmitted through the bite of various species of mosquitoes. In Indonesia, the existence of filariasis cases are still very concerning. Jati Sampurna and Jati Karya villages in Pondokgede Sub-district, Bekasi District, West Java have been known as filariasis endemic area. Length of stay is presumed as one of many factors that affects filariasis occurrence in those villages. This study aimed to determine the distribution of anti-filarial IgG4 on the region and its comparison with the length of stay and residence status. This study was based on secondary data. Secondary data were obtained from primary research data done by cross-sectional method. These data were used to assess the correlation of filarial infection risk factors in pregnant women living in endemic areas based on the distribution of anti-filarial IgG4 in Pondok Gede, Bekasi district, West Java. The study showed that there was an increase in anti-filarial IgG4 against residence status $(p=0.017)$ and a positive correlation between the number of anti-filarial IgG4 with length of stay in years $(p=0.003)$. (FMI 2017;53:217-219)
\end{abstract}

Keywords: anti-filarial IgG4; length of stay; residence status

Correspondence: Jeffry Adijaya Susatyo, Medical Doctor Program, Faculty of Medicine, Universitas Indonesia Email: jeffryadijaya@yahoo.com

\section{INTRODUCTION}

Filariasis is a contagious disease caused by worms of the genus Filaria which transmitted through the bite of various species of mosquitoes. This disease is known as kaki gajah in Indonesian terms or elephantiasis with three species of filarial worm identified which are Wuchereria brancofii, Brugia malayi, and Brugia timori (Ilyas 1990, Center for Disease Control and Prevention 2010) that are considered as the cause of filariasis. The numbers of filariasis cases in Indonesia are very concerning. In 2009, it was estimated that there are more than 125 million people were at risk of LF infection living in 337 endemic districts, but only 11,914 chronic cases have been reported. Based on the mapping data, the overall prevalence of LF in the endemic districts is ranging from 1\%-39\% and almost all islands are endemic (Sub directorate of Filariasis and Schistosomiasis 2010, Kementrian Kesehatan Republik Indonesia 2011)

Table 1. Mf rate (\%) and number of districts in several islands in Indonesia

\begin{tabular}{lcc}
\hline \multicolumn{1}{c}{ Islands } & Mf Rate (\%) & Number of districts \\
\hline Sumatera & $1-18.5$ & 139 \\
Kalimantan & $1-26$ & 55 \\
Java & $1-9.2$ & 32 \\
Sulawesi & $1-28.21$ & 37 \\
Maluku + Papua + & $1.14-38.57$ & 74 \\
West Papua + Nusa & & \\
Tenggara (NTT + & & \\
NTB) + North & & \\
Maluku & & \\
\hline
\end{tabular}


Jati Sampurna and Jati Karya Village in Pondokgede sub-district, Bekasi district, West Java has been known as filariasis endemic area. As a part of built-up area around the capital (Jabodetabek) these villages are prone to urbanization and lots of the inhabitants are immigrants from other region in Indonesia. It is presumed that length of stay is one of the many factors that may affect filariasis incidence in these villages (Hastini 1994, Parslow et al 2003, Sutanto et al 2009, WHO 2011). The level of anti-filarial IgG4 may rise in native inhabitants of these villages and immigrants that have stayed for a long period of time. This study aimed to determine the distribution of anti-filarial IgG4 on the region and its comparison with the length of stay and residence status. We hope that by knowing the distribution of anti-filarial IgG4 in comparison with length of stay and residence status, a more appropriate measure can be done to handle the disease in filariasis endemic regions.

\section{MATERIALS AND METHODS}

This study is based on secondary data. The data were obtained from primary research data done by crosssectional method on the association of risk factors of filarial infection in pregnant women living in endemic areas based on the distribution of anti-filarial IgG4 in Pondokgede, Bekasi district, West Java. These data were used to evaluate the relation between length of stay and residence status with the distribution of antifilarial IgG4. Data obtained were put on a master table and categorized according to the analyzed variables. It was then analyzed with Chi-square and Mann-Whitney test to achieve a conclusion.

\section{RESULTS}

Jati Sampurna and Jati Karya village were two filariasis endemic areas. Study on both villages was done to pregnant women on third trimester pregnancy. As many as 286 mothers were tested for filarial antigen and antifilarial IgG4. A cut off point of 503.3750 was used for the result of anti-filarial IgG4 testing to separate the value between high and low anti-filarial IgG4. This classification was then compared with residence status (native and immigrant). Mann-Whitney test was used due to abnormal distribution of the data seen on Figure 1 .

Chi-square test was done to find out the correlation between anti-filarial $\mathrm{IgG} 4$ and residence status, with result as seen on chart $2(\mathrm{p}=0.017)$

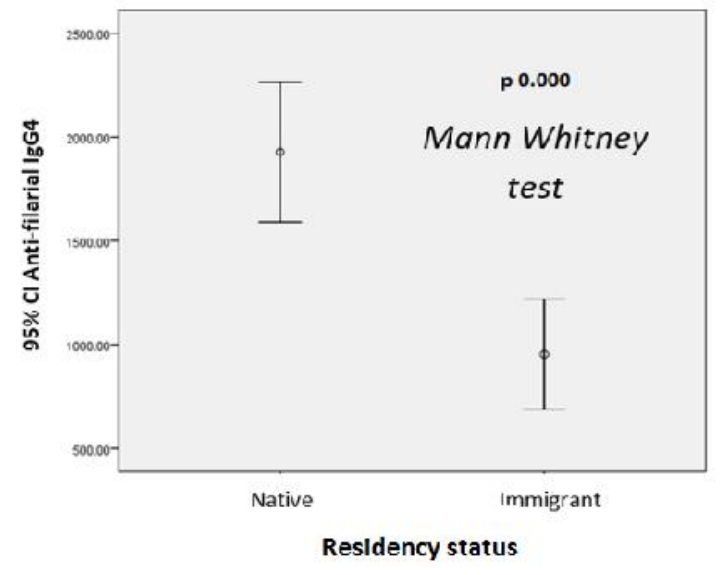

Fig. 1. Residency status and anti-filarial IgG4 comparison.

\begin{tabular}{|c|c|c|c|c|}
\hline & \multicolumn{3}{|c|}{ Antifilarial IgG4 } \\
\hline & & High & Low & Total \\
\hline \multirow{3}{*}{ 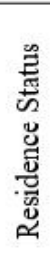 } & Native & $\begin{array}{c}119 \\
(69.6 \%)\end{array}$ & $\begin{array}{c}52 \\
(30.4 \%)\end{array}$ & $\begin{array}{c}171 \\
(100 \%)\end{array}$ \\
\hline & Immigrant & $\begin{array}{c}51 \\
(54.8 \%)\end{array}$ & $\begin{array}{c}42 \\
(45.2 \%)\end{array}$ & $\begin{array}{c}93 \\
(100 \%)\end{array}$ \\
\hline & Total & $\begin{array}{c}170 \\
(64.4 \%)\end{array}$ & $\begin{array}{c}94 \\
(35.6 \%)\end{array}$ & $\begin{array}{c}264 \\
(100 \%)\end{array}$ \\
\hline
\end{tabular}

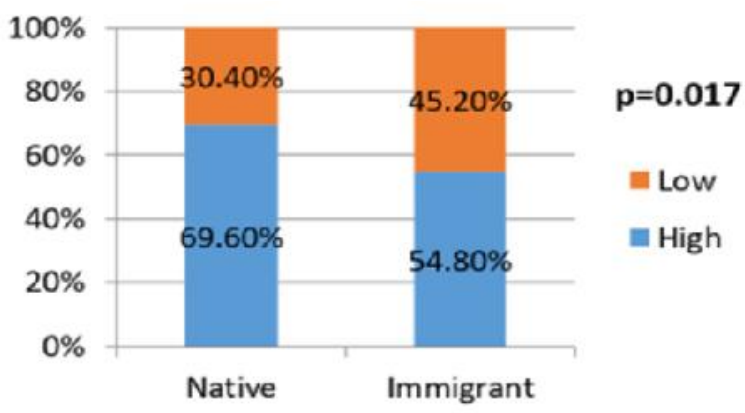

Fig. 2. Proportion of anti-filarial IgG4 compared to residence status.

Out of 171 native inhabitants of the villages, $69.6 \%$ had high levels of IgG4, while only $54.8 \%$ out of 93 immigrants had high levels of IgG4. This shows that native inhabitants had higher IgG4 levels in general than immigrants. The longer the time that the inhabitants spent in these endemic areas might increase the risk of infection of filariasis agents. 


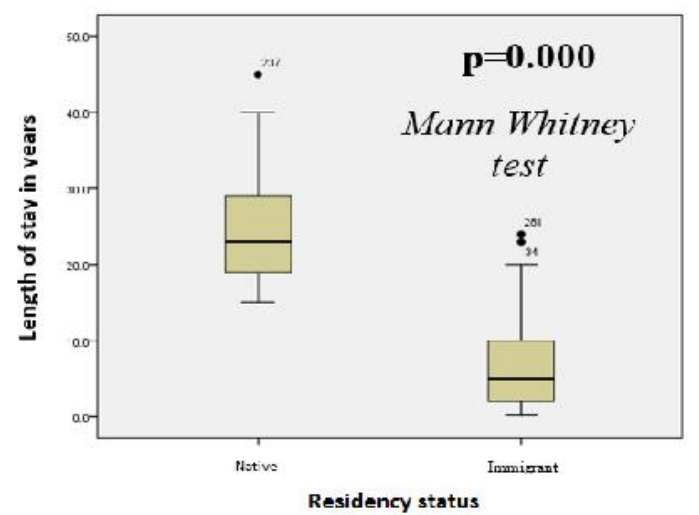

Fig. 3. Comparison between length of stay and residence status.

By using Pearson test, we can see the correlation between length of stay and anti-filarial IgG4 levels.

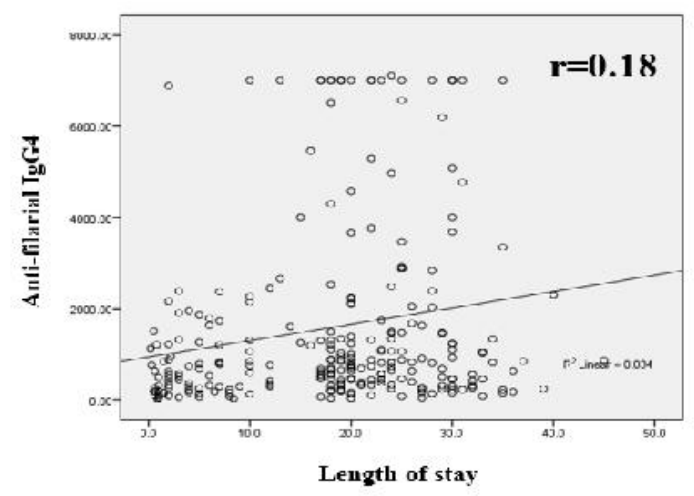

Fig. 4. Correlation between length of stay and antifilarial IgG4 level.

There is a positive correlation between length of stay and anti-filarial IgG4 level. Most subjects are more likely to have a high anti-filarial IgG4 level the longer they stay in those endemic areas.

\section{DISCUSSION}

Filariasis infection occurs when parasites are transmitted to humans through mosquitoes. A single mosquito needs months to develop into a vector for filariasis. The longer someone stays in tropical or subtropical area of filariasis endemic area, the higher the risk of infection (Hastini 1994, Parslow et al 2003, Sutanto et al 2009, WHO 2011) While anti-filarial IgG4 level cannot be used to measure the incidence of filarial infection, high amount of IgG4 level shows that someone has been exposed to filarial antigen for a long time that their body develops antibodies to counter it.
This study showed that amount of time someone stays in the area affects their anti-filarial IgG4 levels. Most of the inhabitants in Jati Sampurna and Jati Karya villages had lived in those villages for more than 20 years, therefore, they are at high risk of infection. This is reflected in the higher amount of anti-filarial IgG4 levels in native inhabitants compared to immigrants.

\section{CONCLUSION}

Length of stay in an endemic area increases the risk of filarial infection, as shown in the increase of $\mathrm{IgG} 4$ levels. Incubation period of a filarial larva lasts for 6 to 12 months (Center for Disease Control and Prevention 2010). Therefore, inhabitants in filariasis endemic areas that have stayed for at least 12 months are recommended to be checked to promote early diagnosis and treatment of filariasis.

\section{REFERENCES}

Center for Disease Control and Prevention (2010). Biology - Life Cycle of Wuchereria bancrofti. [Updated 2010 November 2]. Available from http:// www.cdc.gov/parasites/lymphaticfilariasis/biology_w _bancrofti.html

Hastini (1994). Reaksi imunologik pada perjalanan penyakit filariasis malayi in cermin dunia kedokteran., Jakarta, Pusat penelitian dan Pengembangan PT. Kalbe Farma. p 14

Ilyas I (1990). Program pemberantasan filaria di Indonesia. In: Cermin dunia kedokteran, Jakarta, Pusat penelitian dan Pengembangan PT. Kalbe Farma, p 64

Kementrian Kesehatan Republik Indonesia (2011). Menkes Canangkan Pengobatan Filariasis di Jawa Barat. [Updated 2011 September 17]. Available from http://www.depkes.go.id/index.php/berita/pressrelease/409-menkes-canangkan-pengobatan-filariasisdi-jawa-barat.html

Parslow TG, Stites DP, Terr AI, Imboden JB (2003). Medical immunology international edition. 10th ed, Singapore, The McGraw - Hill Companies, Inc., p 95

Sub directorate of Filariasis and Schistosomiasis, Directorate of Vector Borne Disease Control, Ministry of Health (2010). National Plan Acceleration Program of Filariasis Elimination in Indonesia 2010-2014

Sutanto I, Ismid OS, Sjarifuddin PK, Sungkar S (2009). Buku ajar parasitologi kedokteran. 4th ed, Jakarta, Balain Penerbit FKUI, p 32-44

WHO (2011). Lymphatic Filariasis. [Updated 2011 March]. Available from http://www.who.int/mediacentre/factsheets/fs102/en 